\title{
シンバルの振動特性に及ぼすハンマリング加エの効果
}

鞍谷 文保 ${ }^{* 1}$, 北林 研人 ${ }^{* 2}$, 小川 涉*3, 吉田 達哉*4 長村 光造 ${ }^{* 5}$, 小出 俊雄 ${ }^{* 6}$, 文珠 義之 ${ }^{* 7}$, 水田 泰次 ${ }^{* 7}$

\section{How the hammering process of cymbals affects their vibration characteristics}

\author{
Fumiyasu KURATANI $^{* 1}$, Kento KITABAYASHI ${ }^{* 2}$, Wataru OGAWA ${ }^{* 3}$, Tatsuya YOSHIDA*4, \\ Kozo OSAMURA $^{* 5}$, Toshio KOIDE ${ }^{* 6}$, Yoshiyuki MONJU ${ }^{* 7}$ and Taiji MIZUTA ${ }^{* 7}$ \\ ${ }^{* 1}, *_{2}, *_{3},{ }^{4}$ Department of Mechanical Engineering, University of Fukui \\ 3-9-1 Bunkyo, Fukui-shi, Fukui 910-8507, Japan \\ ${ }^{* 5}$ Research Institute for Applied Sciences \\ 49 Tanaka Ooicho, Sakyo-ku, Kyoto-shi, Kyoto 606-8202, Japan \\ ${ }^{* 6}$ Koide Works, Ltd. (Koide Cymbals) \\ 1-22-32 Kamisyoukakuji, Hirano-ku, Osaka-shi, Osaka 547-0006, Japan \\ ${ }^{* 7}$ Osaka Alloying Works, Co., Ltd. \\ 45-5-9 Shirakatacho, Fukui-shi, Fukui 910-3138, Japan
}

Received: 10 March 2017; Revised: 15 May 2017; Accepted: 25 June 2017

\begin{abstract}
Cymbals are percussion instruments that vibrate and radiate sounds when hit with a stick or when used in pairs. The sound radiated from a cymbal depends on its vibration characteristics. Cymbals are made through spin forming, hammering and lathing processes. The spin forming creates the domed shape of cymbals, determining the basic vibration characteristics. The hammering and lathing make specific sound quality adjustments by changing the vibration characteristics. In this paper, we focus on how the hammering affects the cymbal's vibration characteristics. The hammering produces many shallow dents over the cymbal's surface, generating residual stresses in it. These residual stresses change the vibration characteristics. We perform finite element analysis of the hammered cymbal to obtain its vibration characteristics. In the analysis, we use thermal stress analysis to reproduce the stress distribution and then with this stress distribution we perform vibration analysis. The results show that the effects of thermal load (i.e., hammering) vary depending on the mode: an increase or decrease in the natural frequency. As a result, the peak frequencies and their peak values in the frequency response function change.
\end{abstract}

Key words : Modal analysis, Finite element anaysis, Cymbal, Hammering process, Frequency response function,

Natural frequency, Stress distribution

\section{1. 緒言}

シンバルは円板状の打楽器で，スティックで吒いたり，二枚のシンバルを吅き合わせることで音を出す．シン バルから放射される音はシンバルの振動特性によりほぼその音質が決まる．シンバルは，ブロンズの薄板円板を シンバル形状に成形する成形工程と，音質を調整するためのハンマリング加工および音溝加工からなる音質調整 工程を経て製品となる，ハンマリング加工は，成形されたシンバルの表面を先端が球状のハンマーで吒くことで 浅い円形のくぼみ（ハンマー痕）を与える加工で，シンバル全体に施される．音溝加工は，シンバルを回転させ

No.17-00110 [DOI:10.1299/transjsme.17-00110], J-STAGE Advance Publication date : 6 July, 2017

"1 正員, フェロー，福井大学学術研究院工学系部門（广910-8507 福井県福井市文京 3-9-1）

*2 学生員, 福井大学大学院工学研究科

*3 正員, 福井大学大学院工学研究科

*4 正員, 福井大学学術研究院工学系部門

*5 応用科学研究所 ( $\bar{T} 606-8202$ 京都府京都市左京区田中大堰町 49)

*6 (株) 小出製作所（小出シンバル）（テ547-0006 大阪府大阪市平野区加美正覚寺 1-22-32）

*7 (株) 大阪合金工業所（广910-3138 福井県福井市白方町 45-5-9）

E-mail of corresponding author: kuratani@mech.u-fukui.ac.jp 
ながら円周上に細く浅い溝を複数掘る加工で，ハンマリング加工の後に行われる. シンバルの基音は成形時の寸 法と形状で決まるが，最終製品としてのシンバル音を生成する上で音質調整工程は不可欠である．しかし，音質 の調整は熟練者の経験に依っており，その工学的な意味は明確ではない.

打楽器の研究として, Rossing (Rossing, 2000) は種々の打楽器の振動と音の特徵をまとめている. Bretos ら (Bretos et al., 1997）は, 有限要素解析と実験解析を基にしたシロフォンとマリンバの調音法を提案している. Wang (Wang, 2011）は，シロフォン，メタルフォン，ゴングの設計における有限要素解析と実験モード解析の利用法を示して いる. Tronchin（Tronchin, 2005）は，ケトルの振動と放射音を実験的に測定し，振動モード形状と放射音の関係 を検討している．川井ら（川井他, 2015）はシンバルの振動モードと音響放射効率の関係を調べている.

シンバルは演奏されると多数の振動モードが励起され, その結果シンバル音には複数の周波数成分が含まれる.

Perrin ら（Perrin et al., 2006, 2008）は，スペックルパターン干渉法，レーザドップラ振動測定法，クラドニパター ン法を用いて振動パターンを測定し, 有限要素解析結果と比較している. その結果から, 複数の振動パターンで は複数の振動モードが重なっていることを明らかにしている. Pinksterboer (Pinksterboer, 1993) は The Cymbal Book の中で, シンバル音は寸法, 形状だけでなく, ハンマリング加工や音溝加工などの製造プロセスに依存すると述 ベている．例えば，ハンマリング加工に関して，ハンマー痕が規則的に配列された場合と明らかに規則性がない 場合では音が異なることを指摘している．しかし，ハンマリング加工がシンバル音に及ぼす影響の検討はシンバ ルメーカーによってなされており, 詳細は公表されていない. そこで著者ら（Kuratani et al., 2016）は，ハンマリ ング加工がシンバル音に及ぼす影響を検討するための第一歩として, 加工後のシンバルの振動特性の解析方法を 示した. しかし，解析方法の妥当性やハンマリング加工の工学的な意味の検討が不十分であった.

本論文では，シンバル製造におけるハンマリング加工の効果を，加工がシンバルの振動特性に及ぼす影響から 検討する. 最初に, 加工後のシンバルの振動特性の解析方法を提示する. ハンマリング加工は, 成形されたシン バルの表面に浅い円形のくぼみ（ハンマー痕）を与える加工で，その結果シンバルに残留応力が生じる. 本論文 では, ハンマリング加工により生じるシンバルの残留応力を熱応力解析で再現し, その応力を考慮した振動解析 を行う. 振動特性の解析結果を実験結果と比較し, 振動特性の解析方法の妥当性を検証する. その後, ハンマリ ング加工の条件 (熱応力解析の温度条件) を変更し, 加工がシンバル振動の周波数応答関数に及ぼす影響を調べ, その結果を基にハンマリング加工の工学的意味を明らかにする．その中で，周波数応答が変化する理由およびそ の基本特性である固有振動数が変化する理由を, ハンマリング加工でシンバルに生じる応力と加工前のシンバル の振動モード形状を基に明らかにする.

\section{2. シンパル}

\section{$2 \cdot 1$ 基本構造}

図 1 に，シンバルの基本構造と各部名称を示す．シンバル中央の膨らんだ部分をベル，外周をエッジ，ベル外 周からエッジまでの湾曲している部分をボウと呼ぶ. 多くのシンバルでは, ベル外周からエッジにかけて厚さが 次第に薄くなる. シンバルの基音は全体の直径や質量で決まるが，ベル部の大きさ，ボウ部の厚さと湾曲の程度 によってもシンバル音は異なる，本論文で取り上げるハンマリング加工は，成形加工時のシンバル音の音質を調 整する重要な工程である.

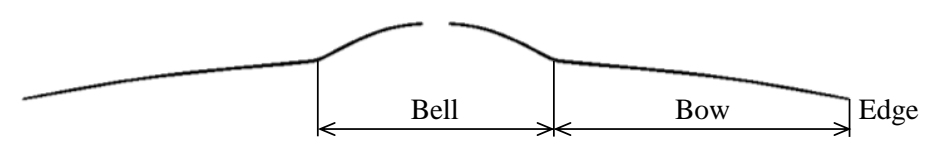

Fig. 1 Cross-sectional view of a cymbal.

\section{$2 \cdot 2$ 製造工程}

シンバルの製造方法はメーカーごとに異なる.ここでは, 小出シンバルで用いられている製造工程を説明する. 最初に, ブロンズのインゴットを薄く切断し, 薄板円板に圧延する. ベル部を熱間プレス加工で成形後, 熱処理 を行う。へら絞り加工でボウ部を成形した後, 旋削加工で黒皮の除去, 板厚調整および外周削りを行う。ここま 
でで基本形状が決まる．この後，図 2 に示すように金型に載せたシンバルを機械ハンマーで吒き，図 3 に示すよ うに直径 $10 \mathrm{~mm}$, 深さ $15 \mu \mathrm{m}$ 程度のくぼみをシンバル全体に与える (ハンマリング加工). 最後に, 旋削加工で 円周上に細く浅い溝を複数掘る (音溝加工).

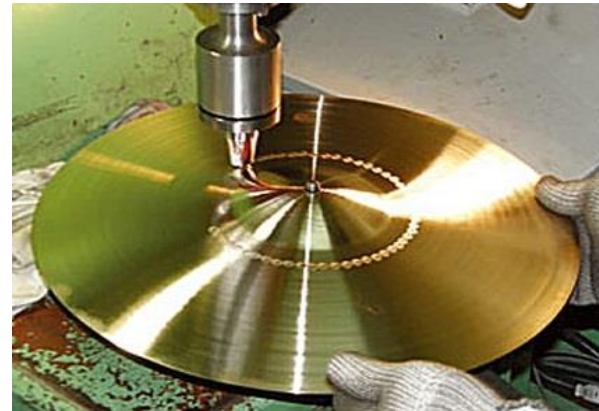

Fig. 2 Hammering process.

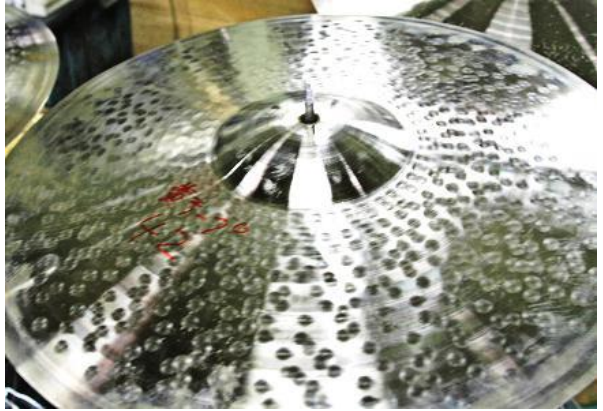

Fig. 3 Hammered cymbal having many dents on the surface.

\section{3. 解析方法}

有限要素解析を用いて, ハンマリング加工されたシンバルの振動特性を解析する方法を説明する (Kuratani et al., 2016).

\section{$3 \cdot 1$ 運動方程式}

ハンマリング加工はシンバルの表面に円形の浅いくぼみを与える塑性加工であり, 加工後のシンバルに残留応 力が生じる. シンバルの質量分布はほとんど変化しないが，剛性特性は大きく変化し，その結果シンバルの振動 特性が変化する. 剛性特性の変化分を $\left[K^{\sigma}\right]$ と表すと, 加工後のシンバルの運動方程式は

$$
[M]\{\ddot{\hat{u}}\}+\left([K]+\left[K^{(\sigma)}\right]+j[D]\right)\{\hat{u}\}=\{f\}
$$

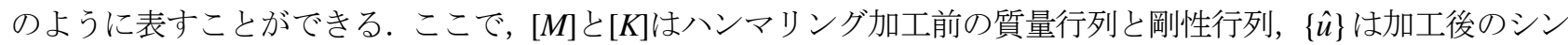
バルの変位ベクトル, $\{f\}$ は外力ベクトルである. $\left[K^{(\sigma)}\right]$ は初期応力剛性行列と呼ばれ，ハンマリング加工で生じ る面内応力が既知となれば算定できる. 本論文で解析要素として用いる四辺形 4 節点シェル要素の場合, 要素ご との初期応力岡性行列は次式となる（鷲津編, 1983）.

$$
\left[K^{\sigma}\right]^{e}=\int_{V}\left[B_{d}\right]^{T}\left[\begin{array}{cccccc}
\sigma_{x} & & & & & \\
\tau_{x y} & \sigma_{y} & & & S y m . & \\
0 & 0 & \sigma_{x} & & & \\
0 & 0 & \tau_{x y} & \sigma_{y} & & \\
0 & 0 & 0 & 0 & \sigma_{x} & \\
0 & 0 & 0 & 0 & \tau_{x y} & \sigma_{y}
\end{array}\right]\left[B_{d}\right] d V
$$

ここで, $\left[K^{\sigma}\right]^{e}$ は要素座標系における $z$ 軸（面外方向）まわりの回転角を除いた 20 自由度（5 自由度 $\times 4$ 節点）に 対応する成分を持つ. $\sigma_{x}$ と $\sigma_{y}$, は要素座標系における面内 $x$ 方向, $y$ 方向の垂直応力, $\tau_{x y}$ はせん断応力で, $\left[B_{d}\right]$ は変位勾配と要素節点変位を関係づける行列である. [D]は減衰行列で，シンバルの材質はブロンズであり材料減 衰は小さいので

$$
[D]=\eta[\hat{K}]
$$

のように加工後の剛性行列 $[\hat{K}]\left(=[K]+\left[K^{(\sigma)}\right]\right)$ に比例すると仮定した. $\eta$ は損失係数である. 


\section{$3 \cdot 2$ 応力解析}

初期応力剛性行列 $\left[K^{(\sigma)}\right]$ を求めるためには, ハンマリング加工されたシンバルの応力分布を知る必要がある. 本論文では, ハンマリング加工による塑性変形を基に応力分布を求めるのではなく, 既報（鞍谷他, 1999）の円板 のローラ圧延に関する研究で用いた方法を適用する. 寸なわち， ハンマリング加工で生じる応力分布と同じ分布 を生じさせると想定される熱負荷を与え，熱応力解析で応力を求める，加工による塑性変形はほぼ円形で，中心 が最も深く，その周辺で急激に浅くなりかつ連続である，そこで，各加工位置での温度分布として，次式のガウ ス分布関数を用いる.

$$
T(r)=T_{c} \exp \left(-\frac{\left(r-R_{c}\right)^{2}}{2 s^{2}}\right)
$$

ここで， $T(r)$ は温度分布中心（加工中心）位置 $R_{c}$ から距離 $r$ の位置での温度， $T_{c}$ は温度分布中心における温度 (温度分布中心温度),$s$ は温度分布の広がりを決める標準偏差である. $T_{c}$ および $s$ は, 実際のハンマリング加工 による塑性変形や振動特性の変化から決定する必要がある.この解析方法は, 弾塑性解析を用いて塑性変形を解 析寸る方法に比べて計算負荷を大幅に低減できる．解析精度については，円板のローラ圧延に関するものである が, 残留応力の測定結果と解析結果の比較がなされている (木村他, 1974). さらに, 著者ら (Osamura et al., 2016) もハンマリング加工後のシンバルの残留応力と解析結果を比較することで, 応力分布の妥当性を示している.

\section{$3 \cdot 3$ 振動解析}

ハンマリング加工後のシンバルの固有角振動数 $\hat{\omega}$ と振動モード $\{\hat{\phi}\}$ は, 固有値問題

$$
\left([\hat{K}]-\hat{\omega}^{2}[M]\right)\{\hat{\phi}\}=\{0\}
$$

を解くことで得られる. 本論文ではハンマリング加工による振動特性の変化として, 周波数応答を比較する. 調 和外力を受けるシンバルの運動方程式は

$$
[M]\{\ddot{\hat{u}}\}+(1+j \eta)[\hat{K}]\{\hat{u}\}=\{F\} e^{j \omega t}
$$

となる.ここで， $\{F\}$ は調和外力の振幅で， $\omega$ は角振動数である.モード重ね合わせ法を用いれば，変位応答は

$$
\{\hat{u}\}=\sum_{r=1}^{N}\left\{\hat{\phi}_{r}\right\} q_{r}
$$

と表される.ここで, $\left\{\hat{\phi}_{r}\right\}$ は加工後の $r$ 次の振動モード， $q_{r}$ はその重み係数， $N$ は採用するモード数である. 重 み係数 $q_{r}$ は

$$
\hat{m}_{r} \ddot{q}_{r}+(1+j \eta) \hat{k}_{r} q_{r}=\left\{\hat{\phi}_{r}\right\}^{T}\{F\} e^{j \omega t}
$$

を解くことで得られる，ここで， $\hat{m}_{r}$ は $r$ 次のモード質量， $\hat{k}_{r}$ はモード岡性である， $q_{r}$ が求まれば，シンバルの 各節点での振動速度は, 次式で算出することができる.

$$
\{V(\omega)\}=j \omega \sum_{r=1}^{N} \frac{\left\{\hat{\phi}_{r}\right\}^{T}\{F\}\left\{\hat{\phi}_{r}\right\}}{-\omega^{2} \hat{m}_{r}+(1+j \eta) \hat{k}_{r}}
$$

\section{$3 \cdot 4$ 固有振動数の変化予測}

本論文では，ハンマリング加工でシンバルに生じる応力分布と加工前のシンバルの振動モード形状を基に，周 波数応答の変化の基本特性である固有振動数が変化する理由を検討する. そのために，ハンマリング加工に対す 
る固有振動数の変化予測式を導く．ハンマリング加工前のシンバルに関する固有值問題 $\left([K]-\omega^{2}[M]\right)\{\phi\}=\{0\}$ を 設計変数 $p_{j}$ で編微分し整理することで, $r$ 次モードの固有角振動数の感度が

$$
\frac{\partial \omega_{r}}{\partial p_{j}}=\frac{\left\{\phi_{r}\right\}^{T}\left(\frac{\partial[K]}{\partial p_{j}}-\omega_{r}^{2} \frac{\partial[M]}{\partial p_{j}}\right)\left\{\phi_{r}\right\}}{2 \omega_{r}\left\{\phi_{r}\right\}^{T}[M]\left\{\phi_{r}\right\}}
$$

のように得られる.ここで, $\left\{\phi_{r}\right\}$ は加工前の $r$ 次モードの振動モードである. 前述のようにハンマリング加工で 質量分布はほとんど変化せず, 剛性行列の変化分が $\left[K^{\sigma}\right]$ とすれば, ハンマリング加工に対する $r$ 次モードの固有 振動数の変化は

$$
\Delta f_{r}=\frac{\left\{\phi_{r}\right\}^{T}\left[K^{(\sigma)}\right]\left\{\phi_{r}\right\}}{8 \pi^{2} f_{r}}
$$

で予測できる．ただし，振動モードは $\left\{\phi_{r}\right\}^{T}[M]\left\{\phi_{r}\right\}=1$ となるように正規化している.

\section{4. 解析方法の検証}

本論文では，ハンマリング加工によるシンバルの残留応力を熱応力解析で再現し，得られた応力分布を基に加 工後の振動特性を求める．振動特性の解析方法の妥当性を検討するために，加工前後のシンバルの周波数応答を 測定し，解析結果と比較する.

本論文で対象とするシンバルは直径 $404 \mathrm{~mm}$ ，ベル直径 $120 \mathrm{~mm}$ ，中心穴径 $13 \mathrm{~mm}$ で，その有限要素（FE）モ デルを図 4 に示す. 解析には有限要素解析ソフトウェア Ansys を用いた. 解析要素はシェル要素 (Shell 181) で, 板厚は $1.5 \mathrm{~mm}$ で均一とした. 半径方向の要素サイズは約 $2 \mathrm{~mm}$ で, 円周方向に関してはベル部が 200 分割, ボウ 部が 600 分割で，外周での最大要素サイズは約 $2 \mathrm{~mm}$ である。なお， ベル部とボウ部の境界では要素サイズが異 なるので，多点拘束を用いて結合している．拘束条件は，実際のシンバルはシンバル中心部をフェルトで支持し ているので, 拘束なしとした. 材料特性として, ヤング率 $E=85.1 \mathrm{GPa}$, 密度 $\rho=8700 \mathrm{~kg} / \mathrm{m}^{3}$, ポアソン比 $v=0.36$, 線膨張係数 $\alpha=1.76 \times 10^{-5} /{ }^{\circ} \mathrm{C}$ を用いた。

ハンマリング加工前後の比較対象として，ピーク周波数が固有振動数と見なせる固有振動数が近接しない低周 波域の周波数応答を選んだ。さらに，その領域に影響が大きい加工位置として，ベル近傍（シンバル中心から半 径 $80 \mathrm{~mm}$ ）を選び，図 5 に示寸ように円周上の 50 箇所にハンマリング加工を行った. 実験では, シンバル中心 から $180 \mathrm{~mm}$ の位置をインパルスハンマで加振し，加振位置での加速度を測定し，周波数領域で積分することで 速度周波数応答関数を求めた．解析では，図 6 に示すように各熱負荷位置は実験と同じ位置（50 箇所）で，各位 置に中心温度 $T_{c}=500^{\circ} \mathrm{C}$, 標準偏差 $s=2.5 \mathrm{~mm}$ の温度分布を与え, 固有振動数と振動モードを求めた. その後, 損 失係数 $\eta=0.001$ とし, 周波数 $1500 \mathrm{~Hz}$ までに含まれる 76 個のモードを用いて実験と同じ位置での速度周波数応答 関数を算出した. なお，周波数分解能は実験に合わせて $\Delta f=1.25 \mathrm{~Hz}$ とした.

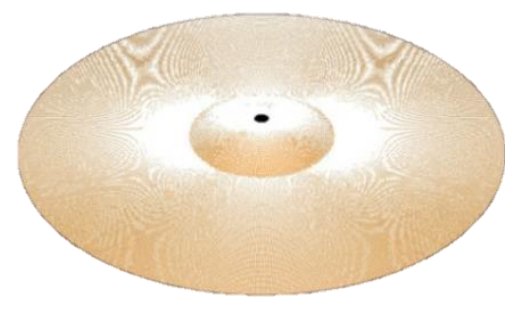

Fig. 4 FE model of a cymbal.

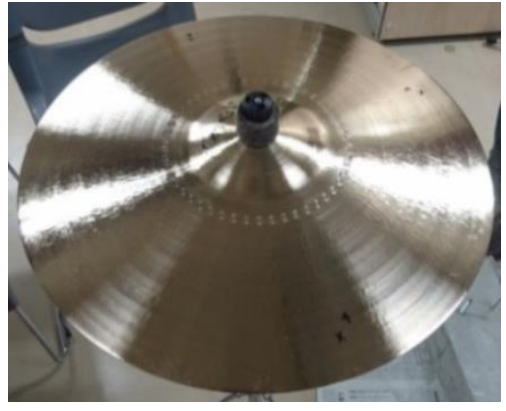

Fig. 5 Hammered cymbal with 50 dents on a $160 \mathrm{~mm}$ diameter circle.

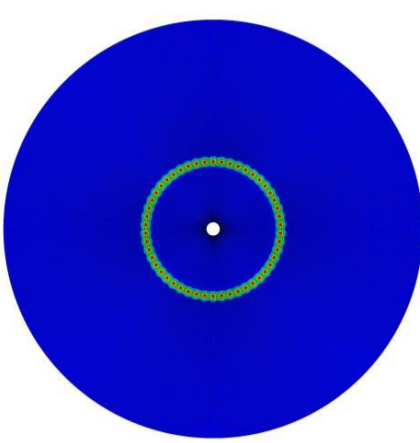

Fig. 6 Thermal loads corresponding to the hammered cymbal. 
図 7 にハンマリング加工前後の周波数応答関数の比較を示す. 図 7(a)が測定結果，図 7(b)が計算結果で，青線 が加工前 (熱負荷なし), 赤線が加工後（温度分布中心温度 $T_{c}=500^{\circ} \mathrm{C}$ ）である. 両図において, ハンマリング加 工前後に 7 個の大きなピークが見られる.これらは順に $(2,0)$ から $(8,0)$ モード（ここで， $(m, n)$ モードとは 節直径数 $m$, 節円数 $n$ のモードを表す) で，加工前後でモードの入れ替わりがないことを確認している. 両図を 比較すると，ハンマリング加工前の FE モデルが実験に用いたシンバルの振動特性を完全には再現できていない ために，加工前の周波数応答関数のピーク周波数が測定と計算で異なっている．しかし，各図の加工前後のピー ク周波数を比較すると，両図とも加工前のピーク周波数に対して加工後のピーク周波数が低下していることがわ かる. したがって, 本論文で用いた熱応力解析を利用したハンマリング加工後の振動特性の解析方法は, 固有振 動数の変化を予測できると考えられる.

なお，ハンマリング加工前の実験結果と解析結果が一致しない大きな理由として, 解析モデルの板厚が $1.5 \mathrm{~mm}$ 均一であることやボウ部の湾曲が実際のシンバルと異なっていることが考えられる. また, 加工前のピーク周波 数に対して加工後のピーク周波数が低下，寸なわち固有振動数が低下寸る理由については 6 ・ 2 節で検討寸る.

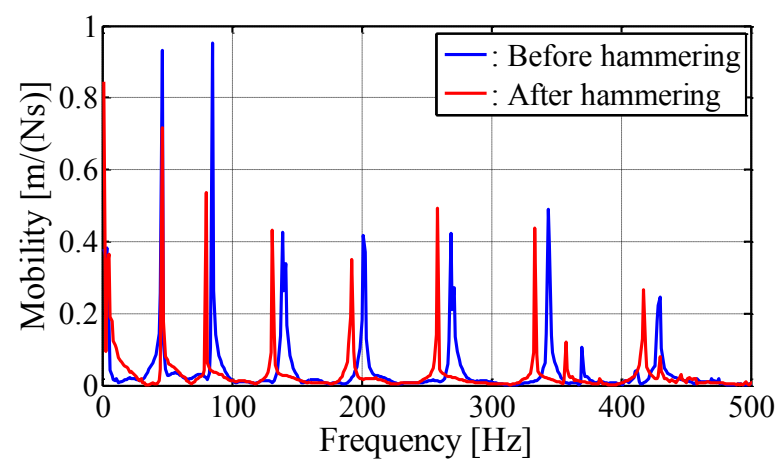

(a) Measured

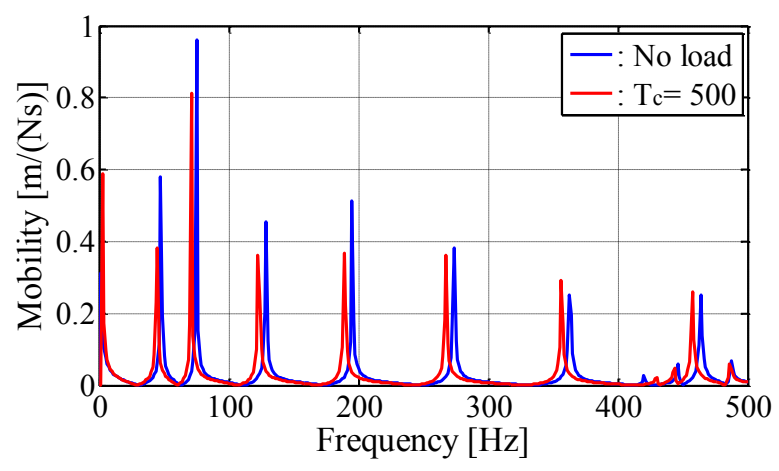

(b) Calculated

Fig. 7 Comparison of velocity frequency response functions (FRFs) before and after hammering. Both the measured and calculated FRFs show that each peak frequency after hammering (and for $T_{c}=500^{\circ} \mathrm{C}$ ) decreases from the corresponding peak frequency before hammering (and for no thermal load).

\section{5. ハンマリング加エが振動特性に及ぼす影響}

実際のシンバルは，ボウ部全体にハンマリング加工が施されている．そこで，図 8 に示すように半径方向に 12 箇所, 円周方向に 50 箇所, 計 600 箇所に熱負荷を与え, 温度分布中心温度（ハンマリング加工の強さ）が振動特 性に及ぼす影響を調べる。

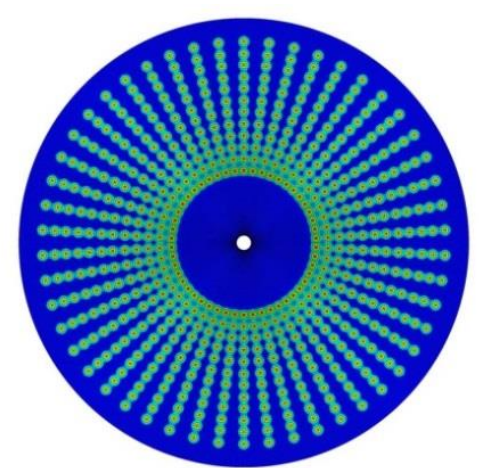

Fig. 8 Thermal loads applied at 12 points in the radial direction and 50 points in the circumferential direction.

\section{$5 \cdot 1$ 周波数応答の変化}

熱負荷なし (加工前) と温度分布中心温度 $T_{c}=300^{\circ} \mathrm{C}, T_{c}=400^{\circ} \mathrm{C}$ (加工後) の場合について, 多数のモードが 励起され周波数応答の違いが現れやすい加振・応答点として, シンバル中心から $180 \mathrm{~mm}$ の位置の節点を選び, 
速度周波数応答関数を求めた。 モード重ね合わせの採用モード数は $15000 \mathrm{~Hz}$ までの 765 モードで，損失係数 $\eta=0.001$, 周波数分解能 $\Delta f=0.1 \mathrm{~Hz}$ とした. 比較する周波数範囲として, 可聴域の中でも聴力感度の高い周波数帯 $2000 \mathrm{~Hz}$ から $5000 \mathrm{~Hz}$ を選んだ. なお， $2000 \mathrm{~Hz}$ 以下には 100 個のモード（6 個の剛体モードと 45 個の重根モード を含む）が存在し， $2000 \mathrm{~Hz}$ から $5000 \mathrm{~Hz}$ の間には 144 個のモード（70 個の重根モードを含む）が存在する.

図 9 に周波数応答関数の比較を示寸. 図 9(a)が熱負荷なし, 図 $9(\mathrm{~b})$ が $T_{c}=300^{\circ} \mathrm{C}$, 図 $9(\mathrm{c})$ が $T_{c}=400^{\circ} \mathrm{C}$ の場合で

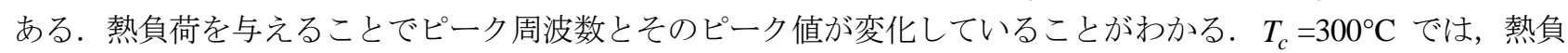
荷なしと比べて $3300 \mathrm{~Hz}, 3700 \mathrm{~Hz}, 4400 \mathrm{~Hz}$ 付近に新たに大きなピークが， $T_{c}=400^{\circ} \mathrm{C}$ では $3700 \mathrm{~Hz}$ 付近に新たに 大きなピークが現れている. これらのことから， ハンマリング加工の強さ（温度分布中心温度）により, 周波数 特性が変化することがわかる，これがハンマリング加工の効果で, 成形加工時のシンバル音の音質の変化につな がる.

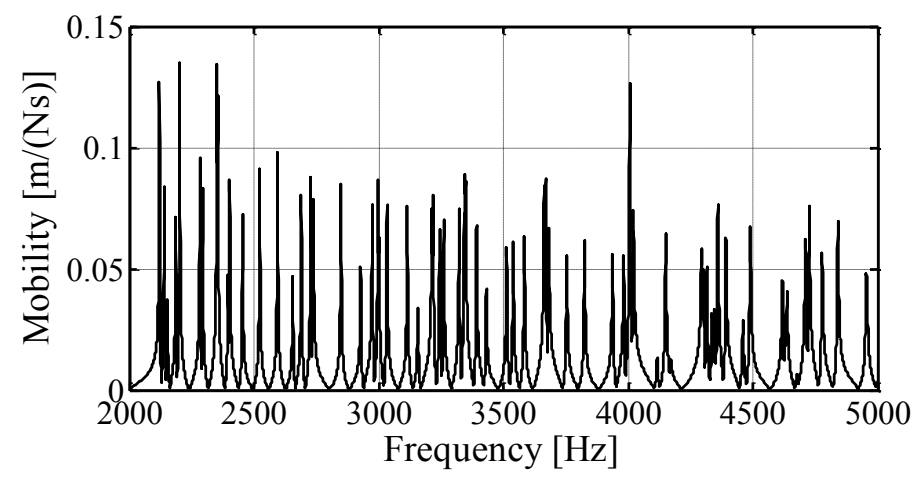

(a) No thermal load

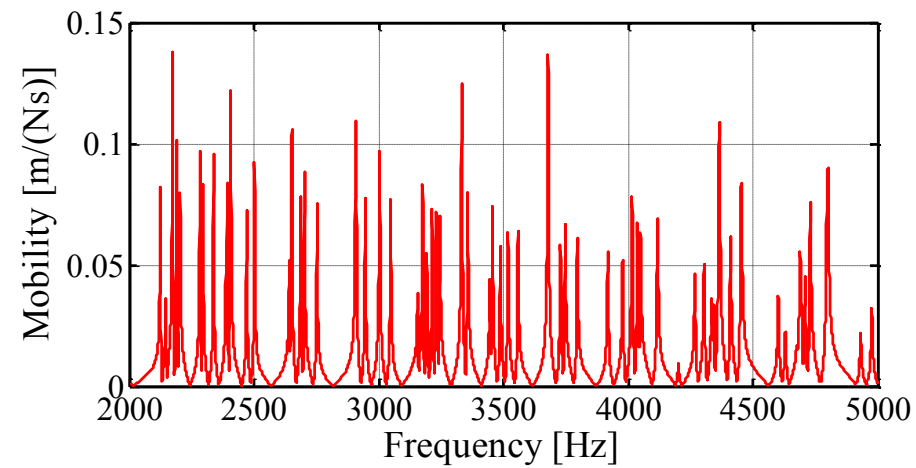

(b) $T_{c}=300^{\circ} \mathrm{C}$,

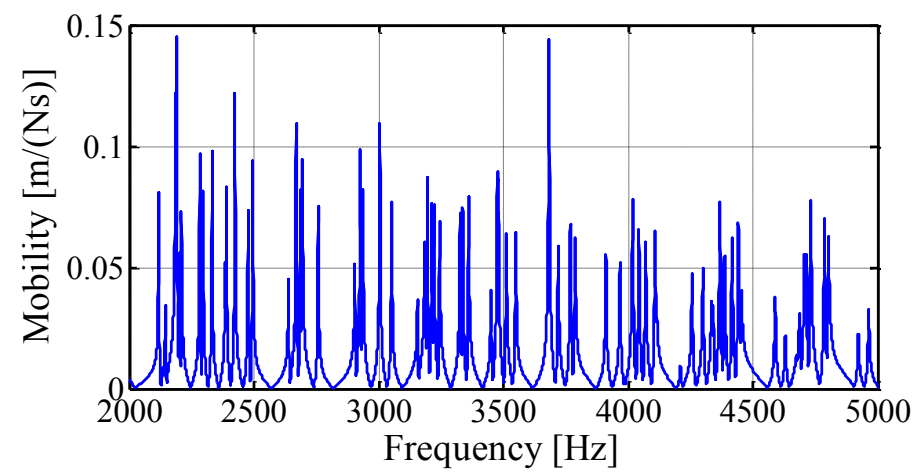

(c) $T_{c}=400^{\circ} \mathrm{C}$

Fig. 9 Comparison of FRFs for the three thermal loads. Changing the thermal load shifts the peak frequencies and significantly changes the corresponding peak values. Especially, for $T_{c}=300^{\circ} \mathrm{C}$, three large peaks are observed between $3000-4500 \mathrm{~Hz}$. 


\section{$5 \cdot 2$ 周波数応答が変化する理由}

前節で示した熱負荷を与えることでピーク周波数およびピーク值が変化する理由を検討する．ここでは，一例 として, 図 9(b)の $T_{c}=300^{\circ} \mathrm{C}$ において大きなピークが観察された $3300 \mathrm{~Hz}$ 付近に注目する. 図 10 に, 図 9 の周波 数範囲 $3310 \mathrm{~Hz}$ から $3370 \mathrm{~Hz}$ の拡大図を示寸. 図 $10(\mathrm{a})$ が熱負荷なし, 図 $10(\mathrm{~b})$ が $T_{c}=300^{\circ} \mathrm{C}$, 図 $10(\mathrm{c})$ が $T_{c}=400^{\circ} \mathrm{C}$ の場合である. また, 表 1 に図 10(a)の 3 個のピークに対応する固有振動数の温度分布中心温度に対する変化を, 図 11 に振動モード形状を示す．なお，熱負荷を与えてもモード形状に大きな変化は見られなかった.

図 10 において，熱負荷なしではピークが三つ存在するが， $T_{c}=300^{\circ} \mathrm{C}$ でピークが二つになり， $T_{c}=400^{\circ} \mathrm{C}$ では 再び三つのピークが現れている. さらに, $T_{c}=300^{\circ} \mathrm{C}$ の $3334 \mathrm{~Hz}$ のピーク值は, 他に比べて大きくなっている.

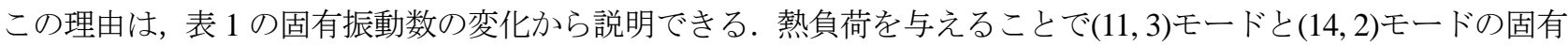
振動数は上昇し， $(4,5)$ モードの固有振動数は低下寸る. $T_{c}=300^{\circ} \mathrm{C}$ のとき $(11,3)$ モードと $(4,5)$ モードの固有振動 数が一致し, 二つのモードのピークが重なることで大きなピークが生成される. $T_{c}=400^{\circ} \mathrm{C}$ では固有振動数の変 化が大きく,$T_{c}=300^{\circ} \mathrm{C}$ で重なっていた二つのピークが分離することで三つのピークが現れる. なお, $3300 \mathrm{~Hz}$ 付 近だけでなく，他の周波数の大きくなったピークについても同様に説明できる.

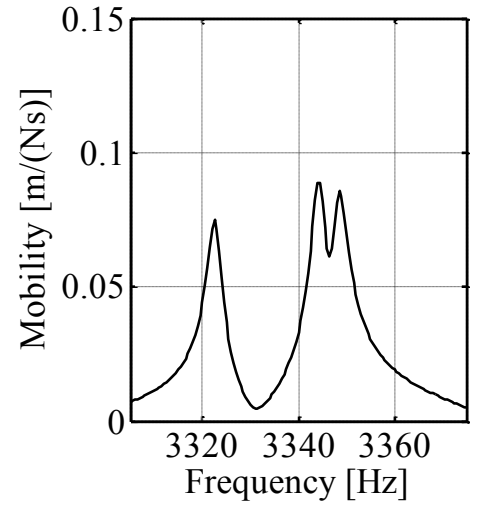

(a) No thermal load

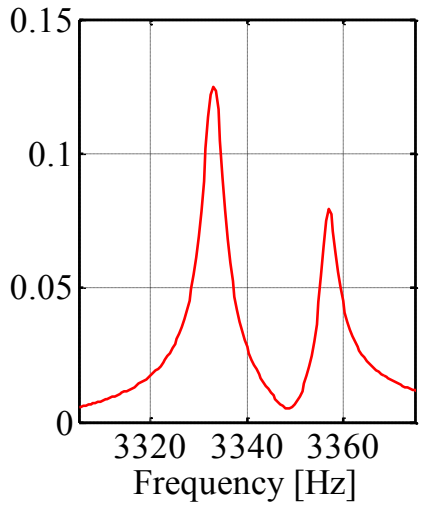

(b) $T_{c}=300^{\circ} \mathrm{C}$

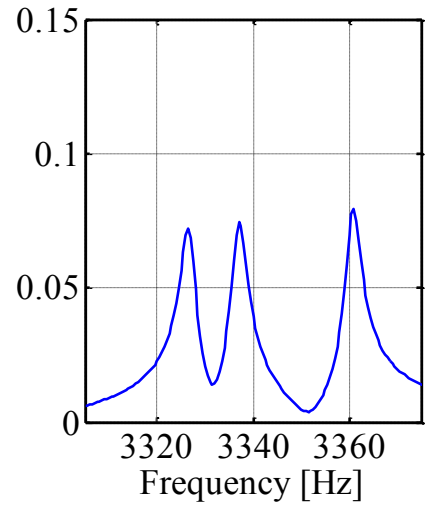

(c) $T_{c}=400^{\circ} \mathrm{C}$

Fig. 10 Change in the frequency response function. The number of peaks decreases from three for no load to two for $T_{c}=300^{\circ} \mathrm{C}$ and then returns to three for $T_{c}=400^{\circ} \mathrm{C}$. For $T_{c}=300^{\circ} \mathrm{C}$, one of the peaks is remarkably large.

Table 1 Dominant modes near $3300 \mathrm{~Hz}$. As the thermal load increases, the natural frequencies of the $(11,3)$ and $(14,2)$ modes increase while the natural frequency of the $(4,5)$ mode decreases. When $T_{c}=300^{\circ} \mathrm{C}$, the natural frequencies are the same for the $(11,3)$ and $(4,5)$ modes, generating a large peak.

\begin{tabular}{c|c|c|c|c}
\hline \hline \multicolumn{2}{c|}{ Thermal load } & No load & $T_{c}=300^{\circ} \mathrm{C}$ & $T_{c}=400^{\circ} \mathrm{C}$ \\
\hline \multirow{4}{*}{ Natural Frequency } & $(11,3)$ & $3323 \mathrm{~Hz}$ & $3334 \mathrm{~Hz}$ & $3337 \mathrm{~Hz}$ \\
& $(14,2)$ & $3344 \mathrm{~Hz}$ & $3357 \mathrm{~Hz}$ & $3360 \mathrm{~Hz}$ \\
& $(4,5)$ & $3348 \mathrm{~Hz}$ & $3334 \mathrm{~Hz}$ & $3327 \mathrm{~Hz}$ \\
\hline
\end{tabular}

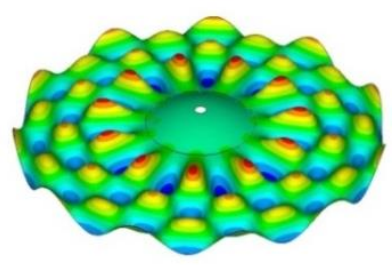

(a) $(11,3)$ mode

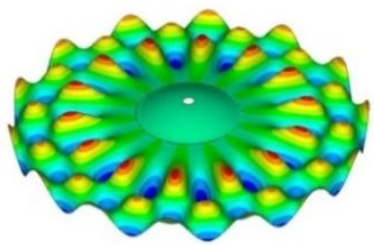

(b) $(14,2)$ mode

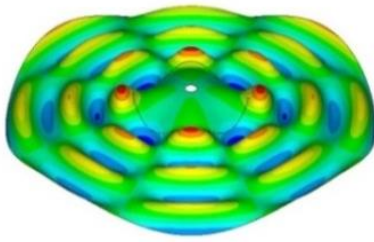

(c) $(4,5)$ mode

Fig. 11 Mode shapes for the modes shown in Table 1. The $(11,3)$ and $(14,2)$ modes have a large number of nodal diameters and a small number of nodal circles while the $(4,5)$ mode has a small number of nodal diameters and a relatively large number of nodal circles. 


\section{6. 固有振動数が変化する理由}

前章で，ハンマリング加工を再現した熱負荷により固有振動数が上昇するモードと低下するモードがあり，そ の結果ピークの数やピークの大きさが変化することを示した. 本章では，モードごとに固有振動数の変化が異な る理由を, 熱負荷（ハンマリング加工）でシンバルに生じる応力分布と加工前のシンバルの振動モード形状を基 に検討する.

\section{$6 \cdot 1$ 熱負荷（ハンリング加エ）による応力分布}

図 12 に, 図 8 の熱負荷位置で温度分布中心温度 $T_{c}=300^{\circ} \mathrm{C}$ の場合の応力分布を示す. 図 $12(\mathrm{a})$ が図 8 の再掲で, 図 12(b)が圧縮の主応力, 図 12(c)が引張の主応力の結果である. 図12(a) と(b)から大きな圧縮応力の位置は熱負荷 位置と一致する.一方, 図 12(a) と(c)から大きな引張応力は熱負荷位置以外に分布していることがわかる.これは, 熱負荷を与えると負荷領域はまわりの構造から拘束を受け圧縮応力を生じ，その反作用として熱負荷のまわりに は引張応力が生じるためである.

本論文では，基礎的な検討として熱負荷を軸対称に与えている．そこで，半径方向の各熱負荷の中心を結んだ 線上の応力（熱負荷中心線上応力）と熱負荷の中心を結んだ 2 本の線の真ん中を通る線上の応力（熱負荷間線上 応力）に注目し，そのシンバル中心からエッジまでの分布を調べる．図 13(a)に熱負荷中心線上応力を，図 13(b) に熱負荷間線上応力を示寸．図中のは各熱負荷の中心位置である．横軸はシンバル中心からの距離，縦軸は応 力值で，赤線が半径方向応力，青線が円周方向応力を表す.

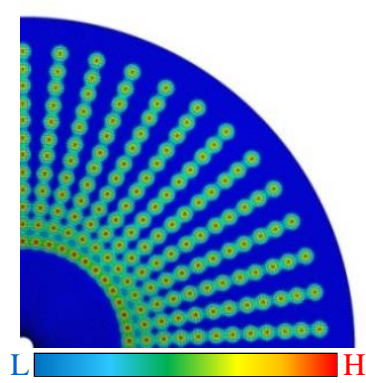

(a) Thermal load

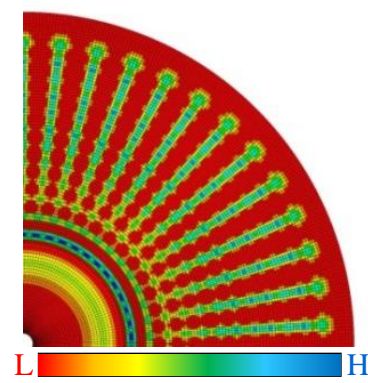

(b) Compressive stress

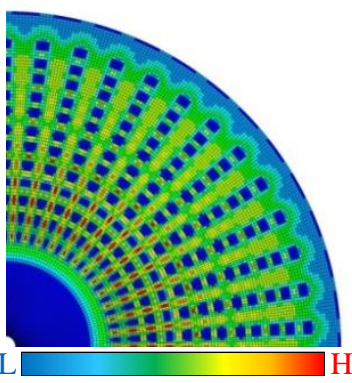

(c) Tensile stress

Fig. 12 Stress distribution. The compressive stresses exist at the locations of thermal loads while the tensile stresses exist around the thermal loads.

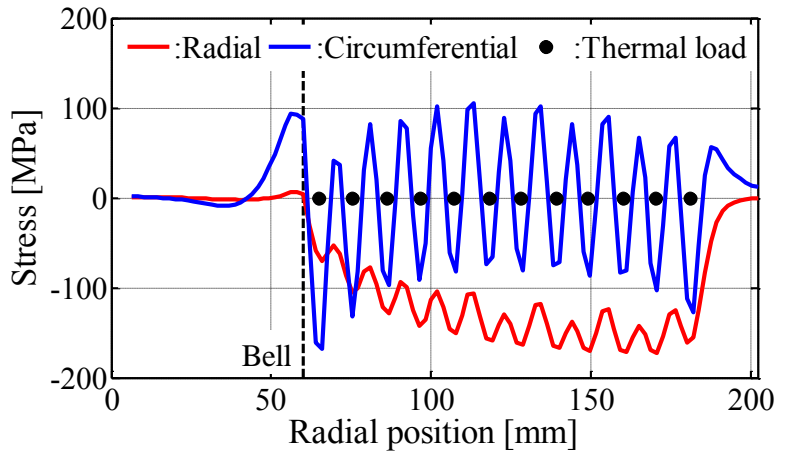

(a) along the line through the thermal loads in the radial direction.

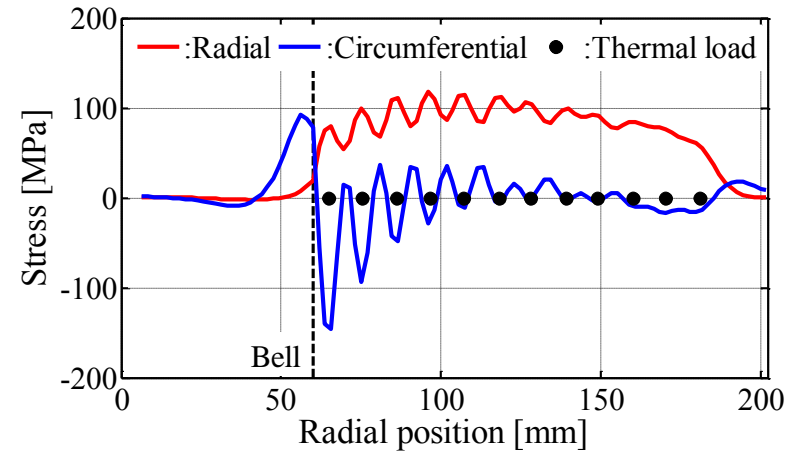

(b) along the line through the center between the two lines through the thermal loads in the radial direction.

Fig. 13 Stress distribution along the radial position. For the radial components, the high stresses distribute over the bow that are all compressive or all tensile. For the circumferential components, they alternate from tensile to compressive along the radial position. 
半径方向応力に関しては, 本論文で与えた熱負荷が図 12(a)に示すように半径方向では接して並んでいるために, 熱負荷中心線上（図 13(a)）では圧縮応力のみとなっている。一方，熱負荷に挟まれる熱負荷間線上（図 13(b)） では引張応力のみとなる. したがって, 半径方向応力は円周方向では大きな圧縮応力と大きな引張応力が交互に 現れる. 円周方向応力に関しては, 熱負荷が同一円周上に並ぶために, 熱負荷と同じ半径位置の円周上では圧縮 応力が, その内側と外側の円周上では引張応力が生じる. その結果, 円周方向応力は図 13(a)と(b)のように半径方 向では圧縮応力と引張応力が交互に現れる. なお, ベル近傍では同一円周上に熱負荷領域が接して並ぶために, 大きな圧縮応力が発生している．また，円周方向の熱負荷の間隔はベル近傍からエッジに向かって広くなるため に，熱負荷間線上の応力は徐々に小さくなっている.

\section{$6 \cdot 2$ 応力分布と振動モードによる固有振動数の変化}

ハンマリング加工による固有振動数の変化は, 式(11)を用いるとハンマリング加工による剛性行列の変化分（初 期応力剛性行列）とハンマリング加工前の振動モードから予測できる. 表 2 に, 図 11 の各モードに関する固有振 動数の変化予測 $\left(T_{c}=300^{\circ} \mathrm{C}\right.$ の初期応力岡性行列の場合）を示寸. 表 2 の 2 列目は表 1 から求めた固有振動数の 変化である. 固有振動数の変化と変化予測は良い一致を示している. したがって, 各モードの固有振動数の変化 の傾向は，ハンマリング加工による剛性行列の変化分とハンマリング加工前の振動モードから予測できることが 確認できた.

Table 2 Prediction of natural frequency change for $T_{c}=300^{\circ} \mathrm{C}$.

\begin{tabular}{c|c|c}
\hline \hline Mode & Natural frequency change & Prediction by Eq.(11) \\
\hline$(11,3)$ & $11.0 \mathrm{~Hz}$ & $11.9 \mathrm{~Hz}$ \\
$(14,2)$ & $12.5 \mathrm{~Hz}$ & $13.2 \mathrm{~Hz}$ \\
$(4,5)$ & $-14.5 \mathrm{~Hz}$ & $-14.6 \mathrm{~Hz}$ \\
\hline
\end{tabular}

初期応力剛性行列はハンマリング加工でシンバルに生じる応力分布に依存する. そこで，初期応力剛性行列と 面内応力の関係を説明し, その後, ハンマリング加工でシンバルに生じる応力分布と加工前のシンバルの振動モ 一ド形状を基に，固有振動数が変化する理由を検討する.

最初に, 要素初期応力剛性行列 $\left[K^{(\sigma)}\right]^{e}$ (式(2)） と面内応力の関係を説明する. 図 11 の各モードは面外変形が 支配的であるので, 面外变位（ $z$ 方向）に関寸る成分だけに注目寸ると本論文で解析に用いた四辺形 4 節点シェ ル要素の場合, $\left[K^{(\sigma)}\right]^{e}$ は $4 \times 4$ の行列となる. 各成分は 4 個の節点間をそれぞれに結ぶ 6 個のばねからなる 4 自由 度モデルの剛性行列と同じになる. 各ばねのばね定数は要素の面内応力で決まり, 面内応力が大きければ值が大 きくなる. さらに, 要素座標系 $x$ 方向のみに引張応力が生じた場合は, $x$ 方向の隣接する節点間のばね定数およ びその要素の対角にある節点間のばね定数は正に, $y$ 方向の隣接寸る節点間のばね定数は負になる. 要素に生じ る応力が圧縮応力の場合は正負が逆になる. 例えば, 要素座標系の $x$ 方向とシンバルの半径方向が一致し, 半径 方向のみに引張応力が生じた場合，半径方向の面外方向の剛性は大きくなる．一方，円周方向の面外方向の剛性 に関しては，円周方向の隣接する節点間のばね定数は負であるが，対角の節点間のばね定数が正であるために， 要素全体としては応力の影響は小さくなると考えられる. したがって, 半径方向の面外剛性の変化を知りたいと きは，半径方向の面内応力に注目すればよいことになる.

式(11)の分子は, 各要素の $\left[K^{(\sigma)}\right]^{e}$ とその要素に関するモード成分から得られた值をすべての要素に関して総和 寸ることで求まる. $\left[K^{(\sigma)}\right]^{e}$ の成分が大きく, かつ節点間の相対変位が大きい場合に, 固有振動数の変化に及ぼす

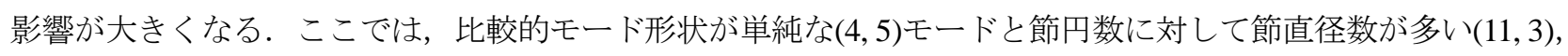
$(14,2)$ モードの典型である図 7 の $(2,0)$ から $(8,0)$ モードに関して, 固有振動数が変化する理由を検討する.

$(4,5)$ モードは, 図 11(c)からわかるように節直径数が少ない（ベル外周長さ約 $380 \mathrm{~mm}$ に対して節数 8 , ボウ部 半径方向長さ約 $140 \mathrm{~mm}$ に対して節数 5）ために, 円周方向の曲げ変形に比べて半径方向の曲げ変形が複雑にな っている. この場合, 面外方向の相対変位が大きい要素は半径方向に多く並んでいると考えることができる. そ こで, 半径方向の面外剛性に影響が大きい図 13 の半径方向応力に注目する. ボウ部にはベル外周からエッジまで 
広がる圧縮応力と引張応力が円周方向では交互に現れる，すなわち，面外方向の相対変位が大きい領域に，剛性 が低下した要素と剛性が増加した要素が交互に現れることになる，しかし，圧縮応力と引張応力の大きさを比較 すると圧縮応力の方が大きいために，面外方向の相対変位が大きい領域全体で考えると圧縮応力の影響が大きく なる，その結果，式(11)の值が負となる．これが，固有振動数が低下した理由と考える.

次に, 節直径数が多い典型である図 7 の $(2,0)$ から $(8,0)$ モードに関して, 固有振動数が低下した理由を検討する. $(2,0)$ から $(8,0)$ モードは節円を持たず節直径数が多いために, 半径方向の曲げ変形に比べて円周方向の曲げ変形が 複雑になっている.この場合, 面外方向の相対変位が大きい要素が円周方向に並んでいると考えることができる. そこで, 円周方向の面外剛性に影響が大きい図 13 の円周方向応力に注目する. ただし, 図 6 の熱負荷位置はベル 近傍だけであるので, 応力分布は図 13 とは異なり熱負荷領域よりエッジ側では応力が急激に小さくなる. しかし, ベル近傍では図 13 のベル近傍と同様に円周方向に大きな圧縮応力が現れる.この圧縮応力のために, 面外方向の 相対変位が大きい円周方向に剛性が低下した要素が並ぶ．その結果，式(11)の值が負となる．これが，固有振動 数が低下した理由と考える. なお， $(2,0)$ から $(8,0)$ モードと異なり， $(11,3),(14,2)$ モードの固有振動数は増加して いる. これは, 図 13 の円周方向応力において, シンバル中心から $100 \mathrm{~mm}$ から $140 \mathrm{~mm}$ の間では圧縮応力より引 張応力の方が大きくなっている. それに対して, 図 11(a)と(b)の振動モードを詳細に観察すると引張応力の方が大 きいシンバル中心から $100 \mathrm{~mm}$ から $140 \mathrm{~mm}$ 間で面外変形が大きくなっているためと考える.

以上のことから, 各モードの固有振動数の変化の傾向は, ハンマリング加工による剛性行列の変化分とハンマ リング加工前の振動モードから予測できることが明らかになった. なお, ハンマリング加工 (熱負荷) による応 力分布が同じでも，応力分布が及ぼす影響が振動モード形状ごとに異なる．その結果として，モードごとの固有 振動数の変化が異なったと考える.

\section{7. 結 言}

本論文では，シンバル製造におけるハンマリング加工の効果として，加工がシンバルの振動特性に及ぼす影響 を検討した．ハンマリング加工後の振動特性を解析する方法として, 加工により生じるシンバルの残留応力を熱 応力解析で再現し, 応力を考慮した振動解析を行った. ハンマリング加工を模擬した熱負荷を与えることで, 周 波数応答関数のピーク周波数およびピーク值が変化することが確認できた. これがハンマリング加工の効果で, 成形加工時のシンバル音の音質の変化につながる. 周波数応答が変化する理由は, 熱負荷により固有振動数が上 昇するモードと低下寸るモードがあり, 複数のモードの固有振動数が近くなるためである. 固有振動数が上昇寸 るモードと低下寸るモードが存在する理由は, シンバルに生じる応力分布が同じでも，応力分布が及ぼす影響が 振動モード形状ごとに異なるためである.

\section{謝辞}

本研究は JSPS 科研費 15 K05860 の助成を受けたものである．記して謝意を表する.

\section{文献}

Bretos, J., Santamaria, C.M. and Moral, J.A., Tuning process of xylophone and marimba bars analyzed by finite element modeling and experimental measurements, Journal of the Acoustical Society of America, Vol.102 (1997), pp.38153816.

川井徹平, 鞍谷文保, 吉田達哉, 桝本貴之, 振動モードに基づくシンバル放射音の特性解析, 日本機械学会北陸信 越支部第 52 期総会・講演会講演論文集 (2015), Paper No.311.

木村志郎, 安藤峰雪, 丸のこのローラ腰入れに関する研究 (第 1 報), 木材学会誌, Vol.20, No.5 (1974), pp.194-204. 鞍谷文保, 矢野澄雄, 岩劽卓三, 沖田耕三, 有限要素法によるローラ圧延された円板の振動解析, 日本機械学会論 文集 C 編, Vol.65, No.631 (1999), pp.857-863.

Kuratani, F., Yoshida, T., Koide, T., Mizuta, T. and Osamura, K., Understanding the effect of hammering process on the vibration characteristics of cymbals, Journal of Physics: Conference Series, Vol.744 (2016), Paper No.12110.

Osamura, K., Kuratani, F., Koide, T., Ogawa, W., Taniguchi, H., Monju, Y., Mizuta, T. and Shobu, T., The correlation between 
the percussive sound and the residual stress/strain distributions in a cymbal, Journal of Materials Engineering and Performance, Vol.25 (2016), pp.5323-5329.

Perrin, R., Swallowe, G.M., Zietlow, S.A. and Moore, T.R., Normal modes of an 18 inch crash cymbal, Proceedings of the Institute of Acoustics, Vol.28, Pt.1 (2006), pp.653-662.

Perrin, R., Swallowe, G.M., Zietlow, S.A. and Moore, T.R., The normal modes of cymbals, Proceedings of the Institute of Acoustics, Vol.30, Pt.2 (2008), pp.460-467.

Pinksterboer, H., The Cymbal Book (1993), pp.67-82, Hal Leonard.

Rossing, T.D., Science of Percussion Instruments, Series in Popular Science, Vol.3 (2000), World Scientific.

Tronchin, L., Modal analysis and intensity of acoustic radiation of the kettledrum, Journal of the Acoustical Society of America, Vol.117 (2005), pp.926-933.

Wang, B., Integration of FEA and EMA techniques for percussion instrument design analysis, Proceedings of 2011 International Conference on System Science and Engineering (2011), pp.11-16.

鷲津久一郎編, 有限要素法ハンドブック 応用編 (1983), pp.145-148, 培風館.

\section{References}

Bretos, J., Santamaria, C.M. and Moral, J.A., Tuning process of xylophone and marimba bars analyzed by finite element modeling and experimental measurements, Journal of the Acoustical Society of America, Vol.102 (1997), pp.38153816.

Kawai, T., Kuratani, F., Yoshida, T. and Masumoto, T., Sound radiation characteristics of cymbals based on mode shapes, Proceedings of 52th JSME Hokuriku Shin-etsu branch conference (2015), Paper No.311 (in Japanese).

Kimura, S. and Ando, M., Studies on tensioning of circular saw by rolling pressure I, Journal of the Japan Wood Research Society, Vol.20, No.5 (1974), pp.196-204 (in Japanese).

Kuratani, F., Yano, S., Iwatsubo, T. and Okita, K., Vibration analysis of disks tensioned by rolling using finite element method, Transactions of the Japan Society of Mechanical Engineers, Series C, Vol.65, No.631 (1999), pp.857-863 (in Japanese).

Kuratani, F., Yoshida, T., Koide, T., Mizuta, T. and Osamura, K., Understanding the effect of hammering process on the vibration characteristics of cymbals, Journal of Physics: Conference Series, Vol.744 (2016), Paper No.12110.

Osamura, K., Kuratani, F., Koide, T., Ogawa, W., Taniguchi, H., Monju, Y., Mizuta, T. and Shobu, T., The correlation between the percussive sound and the residual stress/strain distributions in a cymbal, Journal of Materials Engineering and Performance, Vol.25 (2016), pp.5323-5329.

Perrin, R., Swallowe, G.M., Zietlow, S.A. and Moore, T.R., Normal modes of an 18 inch crash cymbal, Proceedings of the Institute of Acoustics, Vol.28, Pt.1 (2006), pp.653-662.

Perrin, R., Swallowe, G.M., Zietlow, S.A. and Moore, T.R., The normal modes of cymbals, Proceedings of the Institute of Acoustics, Vol.30, Pt.2 (2008), pp.460-467.

Pinksterboer, H., The Cymbal Book (1993), pp.67-82, Hal Leonard.

Rossing, T.D., Science of Percussion Instruments, Series in Popular Science, Vol.3 (2000), World Scientific.

Tronchin, L., Modal analysis and intensity of acoustic radiation of the kettledrum, Journal of the Acoustical Society of America, Vol.117 (2005), pp.926-933.

Wang, B., Integration of FEA and EMA techniques for percussion instrument design analysis, Proceedings of 2011 International Conference on System Science and Engineering (2011), pp.11-16.

Washizu, K. (Ed.), Handbook of Finite Element Method: Application (1983), pp.145-148, Baifukan (in Japanese). 